\title{
INDUCTION OF MYELOMA PROTEIN SYNTHESIS IN EHRLICH ASCITES TUMOR CELLS BY THE ADDITION OF A PLASMA CELL TUMOR (X5563) RNA ${ }^{1)}$
}

\author{
KAZUO MORIWAKI \\ National Institute of Genetics, Misima, Japan
}

Received 12 August, 1964

Recently several investigators have shown the existence of a sequential pathway of genic expression from DNA to specific protein synthesis through RNA in mammalian cells (Schweet et al. 1958; Weiss 1960; Hiatt 1962; Sibatani et al. 1962). On the other hand it is conceivable that there are many complicated regulatory mechanisms controlling genic expression in higher animals. In order to reveal these mechanisms of regulation one useful approach is to isolate molecular genetic information at different steps in the chemical sequences of genic expression. Several such attemps have been successful. For instance, in a cell free system prepared from rabbit reticulocytes, a messenger RNA-like fraction obtained from sheep reticulocytes could produce sheep hemoglobin (Lamfrom 1962). In intact mammalian cells, other heterologous proteins could be synthesized by the addition of exogenous RNA (Niu et al. 1961; Weisberger 1962) or DNA (Szybalska and Szybalski 1963).

The present study represents an attempt to obtain molecular genetic information (RNA) related to myeloma protein synthesis. Specifically, the attempt was made to induce synthesis of gamma myeloma protein by Ehrlich ascites tumor cells by exposing these cells to a high concentration of RNA extracted from a plasma cell tumor. The Ehrlich ascites cells are incapable of synthesizing this protein without this treatment. Moreover, dependence of gamma myeloma protein synthesis on DNA was tested by actinomycin $\mathrm{D}$, which inhibits DNA transcription.

\section{MATERIALS AND METHODS}

Tumor strains: The plasma cell tumor (X5563) used in this study was kindly supplied by Dr. M. Potter of the National Institutes of Health, U.S.A., in 1962. Since then it has been maintained in $\mathrm{C} 3 \mathrm{H}$ mice by serial subcutaneous transplantation every two weeks. The stable character of the tumor cells to produce a gamma myeloma protein in large amount was ascertained by means of paper electrophoresis.

As a recipient of the plasma cell tumor RNA, hyperdiploid Ehrlich ascites tumor cells (ELD) were employed. The tumor strain was obtained from the Children's

1) Contribution from the National Institute of Genetics, Japan. No. 517. 
Cancer Research Foundation, Boston, in 1958, and has been maintained in Misima using inbred Swiss albino mice.

Preparation of cell suspension of X5563 tumor: In order to treat the plasma cell tumor most effectively with actinomycin D, a cell suspension was prepared from the solid form. The solid tumor of X5563 was minced in ice-cold saline and triturated repeatedly with a $5 \mathrm{ml}$ pipette, and then filtered through double layers of gauze to remove the tissue debris. The crude cell suspension was centrifuged at $500 \mathrm{rpm}$ for one minute. Clumped cells could be removed by precipitation in this procedure. The fine cell suspension was again centrifuged at $1,500 \mathrm{rpm}$ for 2 minutes at $5^{\circ} \mathrm{C}$. The packed cells were resuspended in isotonic saline solution and further washed by centrifugation at $1,500 \mathrm{rpm}$ for 2 minutes. Finally the packed cells were resuspended in tissue culture medium (TC 199) containing actinomycin D at a concentration of $5 \mu \mathrm{g} / \mathrm{ml}$.

Preparation of rabbit antiserum for the gamma myeloma globulin of $X 5563$ tumor: The blood containing the gamma myeloma protein was drawn from the inguinal region of $\mathrm{C} 3 \mathrm{H}$ mice bearing the $\mathrm{X} 5563$ tumor. After clotting the plasma was separated and dialysed against $0.005 \mathrm{M}$ sodium phosphate buffer of $\mathrm{pH} 6.8$ for 8 hours at $5^{\circ} \mathrm{C}$. The dialyzed plasma was centrifuged to remove the small amount of precipitate formed during dialysis. The supernatant protein solution, equivalent to $3 \mathrm{ml}$ plasma, was applied to a diethylaminoethyl (DEAE)-cellulose column $(25 \times 300 \mathrm{~mm})$ and the

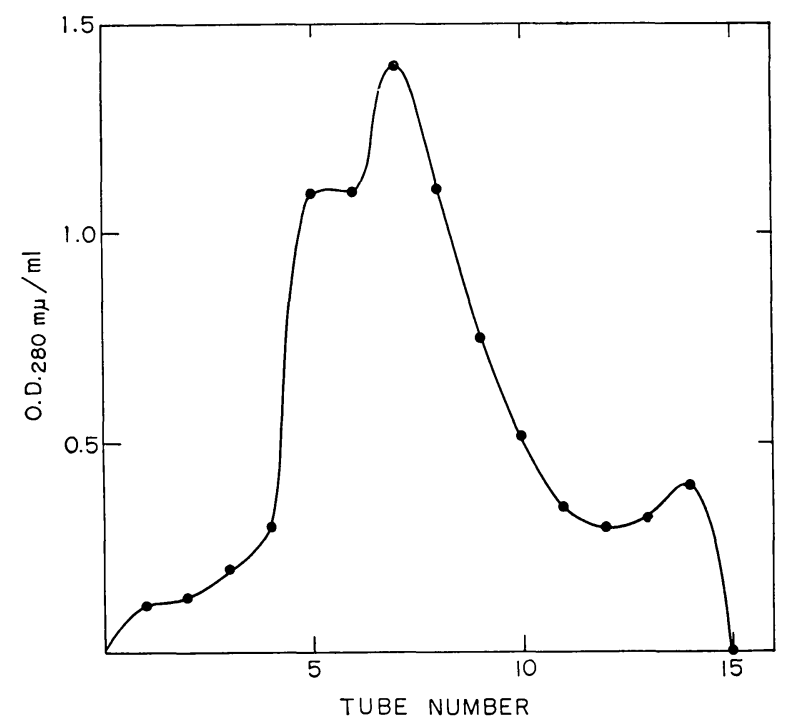

Fig. 1. Elution chromatogram of myeloma globulin in DEAE-cellulose column. Protein solution in $0.005 \mathrm{M}$ sodium phosphate of $\mathrm{pH}$ 6.8 applied to DEAE-column $(25 \times 300 \mathrm{~mm})$ and eluted with 75 $\mathrm{ml}$ of sodium phosphate buffer, $\mathrm{pH} 6.8$ and $0.01 \mathrm{M}$. Optical density in each divided fraction of $5 \mathrm{ml}$ was determined at 280 $\mathrm{m} \mu$. Myeloma protein fraction appeared in 5 tubes, from No. 5 to No. 9 . 
proteins were eluted with $75 \mathrm{ml}$ of 0.01 sodium phosphate buffer, $\mathrm{pH}$ 6.8. The optical density in each divided fraction of $5 \mathrm{ml}$ was determined at $280 \mathrm{~m} \mu$, and the elution chromatogram is shown in Figure 1. The myeloma protein fractions, tube numbers 5 to 9 , were collected and chilled at $-5^{\circ} \mathrm{C}$. To the collected effuluent cold ethanol was added at the final concentration of $25 \%$. That the globulin fraction was precipitated by those treatments could be demonstrated in the paper electrophoretic patterns as demonstrated in Figure 2.

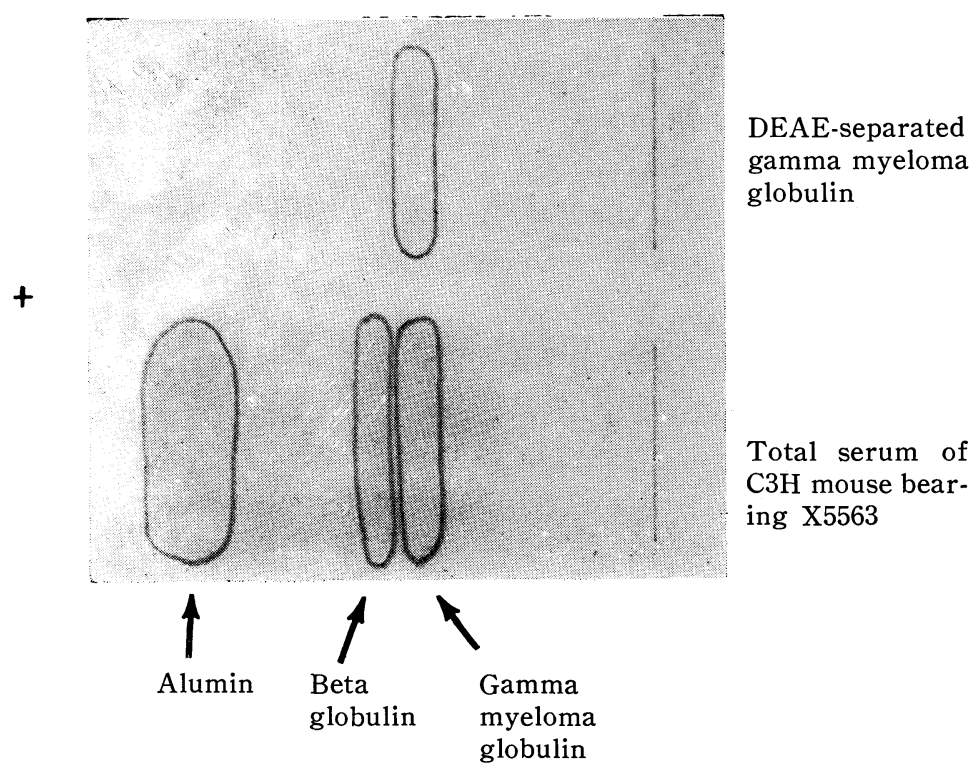

Fig. 2. Paper electrophoresis of gamma myeloma protein separated by DEAE-cellulose column. Condition of electrophoresis; $\mathrm{pH} 8.8$, veronal buffer, $\mu=0.05$.

The precipitate was dissolved in isotonic saline solution at a concentration of O.D. $280 \mathrm{~m} \mu$ of $2.8 / \mathrm{ml}$. The globulin solution of $0.5 \mathrm{ml}$ was injected intravenously into an adult rabbit every 3 days for 2 weeks. Two weeks later the anti-myeloma serum was prepared from the animal. Furthermore, the antigenic components for the $\mathrm{C} 3 \mathrm{H}$ mouse and the Ehrlich ascities tumor were removed from this antiserum by adsorption with adequate amount of $\mathrm{C} 3 \mathrm{H}$ mouse erythrocytes and Ehrlich ascites tumor cells.

In the present experiment, 4 volume of the antiserum was equivalent to one volume of the antigen (O.D. ${ }_{280 \mathrm{~m} \mu}=2.8 / \mathrm{ml}$ ). The equivalence point of the antiserum with the myeloma protein contained in the neoplastic plasma cells was also determined. The protein extracted from $10^{9}$ cells of the tumor was equivalent to one $\mathrm{ml}$ of the antiserum.

Extraction of the plasma cell tumor RNA: About $5 \mathrm{~g}$ of the plasma cell tumor were minced in the ice-cold isotonic saline buffered at $\mathrm{pH} 7.6$ by tris-maleate, and 
then homogenized in 10 strokes in a Potter-type glass homogenizer. To the homogenate, adjusted to a volume of $25 \mathrm{ml}$ by buffered saline, $25 \mathrm{ml}$ of water-saturated phenol was added and the resulting mixture was stirred for 30 minutes at $5^{\circ} \mathrm{C}$. Centrifugation was performed for 30 minutes at $5^{\circ} \mathrm{C}$ and at $4,000 \mathrm{rpm}$ to separate the aqueous phase and the interphase from the phenol phase. The aqueous phase was removed by suction and stored. The interphase was also removed by suction and 20 $\mathrm{ml}$ of $0.1 \%$ lauryl sulfate solution containing $0.05 \mathrm{M}$ tris-maleate buffer, $\mathrm{pH} 7.6$, and $3 \mathrm{mM} \mathrm{MgCl}{ }_{2}$ was added to it. The stirring was performed for 5 minutes at $5^{\circ} \mathrm{C}$, for 3 minutes at $55^{\circ} \mathrm{C}$ and again for 10 minutes at $5^{\circ} \mathrm{C}$. The mixture was centrifuged for 30 minutes at $5^{\circ} \mathrm{C}$ and at $4,000 \mathrm{rpm}$. The separated aqueous phase was then combined with the aqueous phase obtained in the first extraction process. Following additions of Na-acetate at a final concentration of $2 \%$ and twice volume of ethanol, RNA could be precipitated. To remove the residual phenol, the precipitate was washed three times with cold ethanol and it was dissolved again in Krebs-Ringer phosphate buffer, pH 7.2, where the RNA concentration was adjusted to O.D. ${ }_{280} \mathrm{~m} \mu$ of $50 / \mathrm{ml}$. Ethanol in the solution was removed by the shaking with ethylether in a separatory funnel and the ether was completely vaporized in vacuum. When neccessary, this solution was treated with RNase at a final concentration of $10 \mu \mathrm{g} / \mathrm{ml}$ of the enzyme at $37^{\circ} \mathrm{C}$ for 60 minutes. Heat treatment of RNA was done at $100^{\circ} \mathrm{C}$ for 5 minutes also using this solution.

RNA treatment: $2 \times 10^{9}$ Ehrlich ascites tumor cells were washed with isotonic saline several times and were suspended in $5 \mathrm{ml}$ isotonic Krebs-Ringer phosphate buffer containing considerably higher concentrations of RNA and stirred gently, $30 \mathrm{rpm}$, for 15 hours at $2^{\circ} \mathrm{C}$.

${ }^{14} \mathrm{C}$-amino acid and the other reagents: $\mathrm{DL}-{ }^{14} \mathrm{C}$-leucine was obtained from the Radiochemical Center, England, with specific radioactivity of $100 \mu \mathrm{c} / \mathrm{ml}$. Actinomycin D was purchased from Merck Co. To suspend X5563 cells in actinomycin experiment, TC 199 medium of DIFCO Co. was employed. For the hydrolysis of RNA, RNase made by N.B.C. was used.

Determination of radioactivity in the myeloma protein fraction and the total soluble protein fraction: Incorporation of the amino acid into the ascites tumor cells was carried out at $37.5^{\circ} \mathrm{C}$ for 2 hours using a Warburg manometer vessel containing $2 \times 10^{9}$ cells and $5 \mu \mathrm{c}{ }^{14} \mathrm{C}$-leucine, with parallel determination of oxygen consumption. After that, non-labeled 1\% DL-leucine in isotonic saline was added to the suspension, which was centrifuged for 5 minutes at $1,500 \mathrm{rpm}$ and $0^{\circ} \mathrm{C}$. This washing by leucine saline was repeated 3 times and the resulting sedimented cells were lysed in distilled water. Disruption of the cells was accomplished by freezing in a dryice-acetone mixture and thawing in $37^{\circ} \mathrm{C}$ warm bath, followed by the homogenization in teflon homogenizer for one minute. The homogenate was centrifuged at $12,000 \mathrm{rpm}$ for 15 minutes at $0^{\circ} \mathrm{C}$, in order to obtain a soluble protein fraction containing gamma myeloma protein. 
To the supernatant, DEAE-purified myeloma protein as a carrier antigen and antiserum equivalent to the antigen were added. The mixture was incubated at $37^{\circ} \mathrm{C}$ for 2 hours and subsequently at $0^{\circ} \mathrm{C}$ for 12 hours.

The antibody-antigen precipitate was obtained by centrifugation at 4,000 rpm for 30 minutes at $0^{\circ} \mathrm{C}$. It was carefully washed 5 times of the similar centrifugations using $1 \%$ leucine saline solution. The final precipitate was dissolved in $0.5 \mathrm{ml}$ of $80 \%$ formic acid and dried on a planchet for counting.

To the soluble protein fraction, which was not precipitated by antiserum, trichloroacetic acid (TCA) was added to a final concentration of $5 \%$. This protein fraction was sedimented by centrifuging $1,500 \mathrm{rpm}$ for 5 minutes, and washed 3 times with cold $5 \%$ TCA containing $1 \%$ leucine. The lipids in the precipitate were removed by three extractions with $80 \%$ hot ethanol, absolute ethanol and $(3: 1)$ ethanol ether. After final washing with the TCA solution, the precipitate was dissolved in $0.5 \mathrm{ml}$ $80 \%$ formic acid and dried on a planchet.

The radioactivities of those samples were counted employing a thin window gas flow counter.

\section{RESULTS}

Oxygen consumption of Ehrlich ascites tumor cells treated with plasma cell tumor $R N A$ : Following contact with the plasma cell tumor RNA at $2^{\circ} \mathrm{C}$ for 15 hours, the oxygen consumption of Ehrlich tumor cells was determined. As shown in Figure 3, an approximately constant rate of respiration could be observed for 3 hours for cells in the three treatment groups; (1) treated with Krebs-Ringer phosphate as a control, (2) treated with RNase digested RNA as another control and (3) cells treated with RNA.

Effect of actinomycin D on the myeloma protein synthesis in X5563 tumor cells: In order to reveal whether there exists a DNA dependence in the myeloma protein synthesis, a cell suspension of X5563 tumor was treated with actinomycin D dissolved in a tissue culture medium (TC 199) at a concentration of $5 \mu \mathrm{g} / \mathrm{ml}$. The actinomycin treatment was performed at $37^{\circ} \mathrm{C}$ for 4 hours in a tissue culture bottle. After incubation, the tumor cells were washed 3 times by centrifugations and resuspended in Krebs-Ringer phosphate containing $5 \mu \mathrm{c}{ }^{14} \mathrm{C}$-leucine. The subsequent procedures to determine the amino acid incorporation into the myeloma protein fraction were the same as those shown in the previous section. Partial inhibition of myeloma protein synthesis by actinomycin occurred, as demonstrated in Table 1 . Actinomycin D at $5 \mu \mathrm{g} / \mathrm{ml}$ scarcely inhibited oxygen consumption, while suspending the cells in tissue culture medium seemed to cause some decrease (Figure 5).

Inhibitions of total soluble protein synthesis in Ehrlich ascites tumor cells and X5563 tumor cells by extracellular RNA: Following treatment with the extracellular RNA for 15 hours at $2{ }^{\circ} \mathrm{C}$, the total soluble protein syntheses of Ehrlich ascites tumor cells and X5563 tumor cells were inhibited in proportion to the concentration of RNA as 


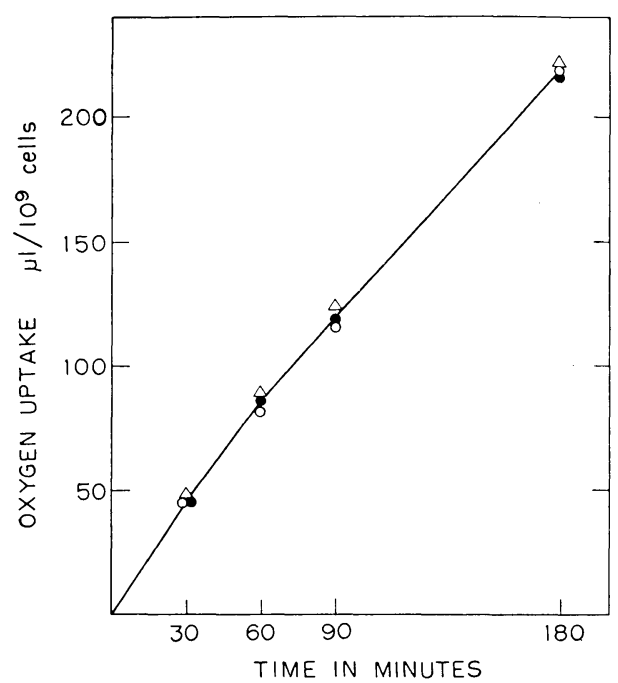

Fig. 3. Oxygen consumption of Ehrlich ascites tumor cells after treatment with extracellular RNA for 15 hours at $2^{\circ} \mathrm{C}$. Oxygen consumption was determined by Warburg manometer at $37.5^{\circ} \mathrm{C}$ and shaking rate of 95 times per minute. Three kinds of symbol represent the conditions of RNA treatment as follows: $O$ : Control, stirred in isotonic Krebs-Ringer phosphate solution. $\triangle$ : Treated with RNase digested RNA of X 5563 tumor. $\Delta$ : Treated with X 5563 RNA.

Table 1. Inhibition of ${ }^{14} \mathrm{C}$-labeled amino acid incorporation into myeloma protein by actinomycin $\mathrm{D}$

\begin{tabular}{|c|c|c|c|}
\hline \multirow{2}{*}{$\begin{array}{l}\text { Duration of treatment } \\
\text { (min) }\end{array}$} & \multicolumn{2}{|c|}{$\begin{array}{c}\text { Incorporated }{ }^{14} \mathrm{C} \text {-leucine in myeloma } \\
\text { protein fraction } \\
\left(\mathrm{cpm} / 10^{9} \text { cells }\right)\end{array}$} & \multirow[t]{2}{*}{ Percentage of inhibition } \\
\hline & - Act. D & + Act. D & \\
\hline 0 & 1,330 & - & - \\
\hline 120 & 780 & 610 & 22 \\
\hline 240 & 740 & 580 & 22 \\
\hline
\end{tabular}

Actinomycin D treatment was carried out in the cell suspension of X5563 tumor in TC 199 medium at the final concentration of $5 \mu \mathrm{g} / \mathrm{ml}$.

illustrated in Figure $4 .{ }^{14} \mathrm{C}$-leucine incorporation into Ehrlich ascites tumor cells was inhibited at almost the same rate either by homologous RNA from Ehrlich tumor or by heterologous RNA from X5563 tumor. An amino acid incorporation experiment was performed with a slice of X5563 tumor. In this case the inhibition was less than that observed in the ascites form tumor, perhaps because of the incomplete difusion of RNA in the slice. 


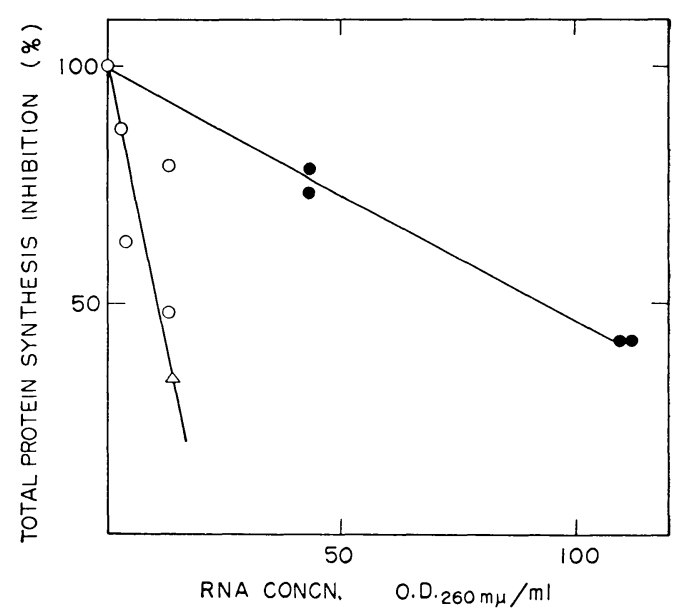

Fig. 4. Inhibition of total soluble protein syntheses in Ehrlich ascites tumor cells and X5563 tumor cells by extracellular RNA. RNA treatments were carried out for 15 hours at $2^{\circ} \mathrm{C}$ and followed by the procedure of ${ }^{14} \mathrm{C}$-leucine incorporation for 2 hours at $37^{\circ} \mathrm{C}$. Each symbol represents the specific combination of RNA and tumor. $O$ : Ehrlich ascites tumor cells were treated with X5563 RNA. $\triangle$ : Ehrlich ascites tumor cells were treated with RNA of Ehrlich tumor itself. @: X 5563 tumor slice was treated with X5563 RNA.

Restoration of depressed synthesis of myeloma protein in X5563 plasma cell tumor by the homologous RNA: As demonstrated in Table 2, X5563 tumor RNA is capable of restoring myeloma protein synthesis in the tumor slice depressed by actinomycin D. As was already shown in Figure 4, amino acid incorporation into the protein fractions was inhibited by the RNA treatment. So, effect of the RNA on myeloma protein synthesis was represented by a ratio of myeloma protein fraction to total soluble protein fraction in ${ }^{14} \mathrm{C}$-leucine incorporation.

The ratio in this case was reduced by actinomycin $\mathrm{D}$, and it could be restored nearly to the control level following RNA treatment.

Synthesis of myeloma protein in Ehrlich ascites tumor cells following treatment with $X 5563 \mathrm{RNA}$ : Incorporations of ${ }^{14} \mathrm{C}$-leucine into myeloma protein and the total soluble protein fraction in Ehrlich ascites tumor cells after treatment with X5563 RNA are demonstrated in Table 3. Compared with the ratios in control cells and RNA treated cells, one can probably recognize the synthesis of myeloma protein in X5563 RNAtreated Ehrlich ascites tumor cells.

Comparison between X5563 tumor RNA and Ehrlich tumor RNA in the abilities to induce the synthesis of myeloma protein: To reveal whether X5563 RNA has a specificity or not in the ability to induce the synthesis of myeloma protein, Ehlich tumor RNA was used in place of X5563 RNA in this experiment. In Table 4, not the ratio of 


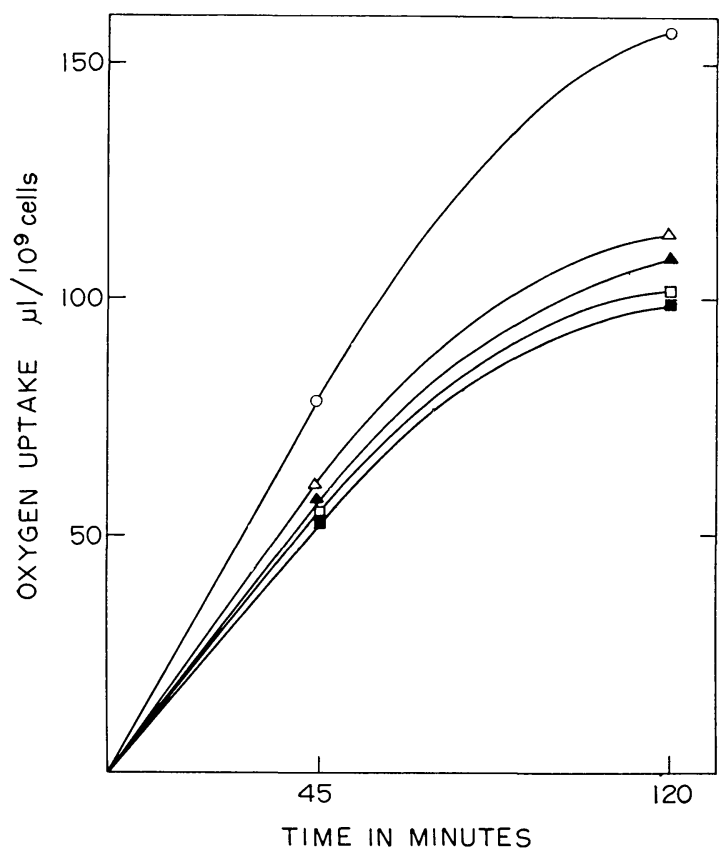

Fig. 5. Manometrically measured oxygen consumption of X 5563 tumor cell suspension after acinomycin D treatment in TC 199 medium. Each symbol represents the conditions of treatments which were carried out at $37^{\circ} \mathrm{C}$. Controls: $O$ : At 0 time, $\triangle$ : Incubated in TC 199 for 2 hours, $\square$ : Incubated in TC 199 for 4 hours, Actinomycin D treatments at a concentration of $5 \mu \mathrm{g} / \mathrm{ml}, \quad \Delta$ : For 2

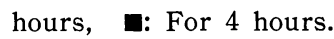

Table 2. Restoration effect of the homologous RNA on the depressed myeloma protein synthesis in X5563 plasma cell tumor

\begin{tabular}{lccc}
\hline \multirow{2}{*}{ Treatment } & \multicolumn{2}{c}{$\begin{array}{c}{ }^{14} \text { C-leucine incorporation } \\
(\mathrm{cpm} / 100 \mathrm{mg} \text { tissue })\end{array}$} & $\begin{array}{c}\text { Ratio of M.P./T.S.P. } \\
\text { in } \begin{array}{c}\text { 14C-leucine } \\
\text { incorp. }\end{array}\end{array}$ \\
\cline { 2 - 4 } & Myeloma protein & Total soluble protein & $0.27(1.00)$ \\
\hline K.R.P. (control) & 264 & 980 & $0.19(0.71)$ \\
\hline Act. D & 110 & 578 & $0.22(0.81)$ \\
\hline Act. D & 161 & 725 & $0.24(0.89)$ \\
X5563 RNA & 100 & 414 & $0.28(1.04)$ \\
\hline
\end{tabular}

RNA used above was extracted from X5563 tumor. Either RNA treatment for 15 hours at $2{ }^{\circ} \mathrm{C}$ and ${ }^{14} \mathrm{C}$-leucine incorporation for 2 hours at $37^{\circ} \mathrm{C}$ were carried out using slice of $\mathrm{X} 5563$ tumor. Actinomycin D tratment was done at the concentration of $5 \mu \mathrm{g} / \mathrm{ml}$ for one hour at $37^{\circ} \mathrm{C}$ before RNA treatment. Following abbreviations were used: K.R.P.; Krebs-Ringer phosphate buffer. Act. D; Actinomycin D. M.P.; Myeloma protein fraction. T.S.P.; Total soluble protein fraction. 
Table 3. Synthesis of myeloma protein in Ehrlich ascites cells following treatment with exogenous RNA extracted from X5563 plasma cell neoplasm

\begin{tabular}{lccc}
\hline \hline \multirow{2}{*}{ Treatment } & \multicolumn{2}{c}{$\begin{array}{c}{ }^{14} \mathrm{C}-\text { leucine incorporation } \\
\left(\mathrm{cpm} / 10^{9} \text { cells }\right)\end{array}$} & $\begin{array}{c}\text { Ratio of M.P./T.S.P. } \\
\text { in 14C-leucine } \\
\text { incorp. }\end{array}$ \\
\cline { 2 - 3 } & Myeloma protein & Total soluble protein & $0.052(1.00)$ \\
\hline K.R.P. (control) & 508 & 9,850 & $0.080(1.54)$ \\
RNA (O.D. 4.5) & 316 & 6,120 & $0.077(1.46)$ \\
RNA (O.D. 17) & 175 & 3,380 & $0.016(1.00)$ \\
\hline K.R.P. (control) & 121 & 7,500 & $0.029(1.81)$ \\
RNA (O.D. 4.5) & 189 & 6,500 & \\
\hline
\end{tabular}

RNA treatments were carried out for 15 hours at $2^{\circ} \mathrm{C}$ with gentle stirring. ${ }^{14} \mathrm{C}$-leucine incorporation was done by incubation of the Ehrlich tumor cells for 2 hours at $37^{\circ} \mathrm{C}$. Following 5 times of freezing and thawing and subsequent centrifugation, myeloma protein fraction was isolated from the supernatant by anti-myeloma rabbit serum and then total solube protein fraction could be obtained by the precipitation with cold TCA. Abbreviations: K.R.P.; Krebs-Ringer phosphate buffer. M.P.; Myeloma protein fraction. T.S.P.; Total soluble protein fraction.

Table 4. Comparison between X5563 tumor RNA and Ehrlich tumor RNA in abilities to induce the synthesis of myeloma protein

\begin{tabular}{|c|c|c|c|}
\hline Exp. No. & Source of RNA & O.D.260 per $\mathrm{ml}$ & $\begin{array}{c}{ }^{14} \mathrm{C} \text {-leucine incorporation into myeloma } \\
\text { protein fraction } \\
\left(\mathrm{cpm} / 10^{9} \text { cells }\right)\end{array}$ \\
\hline \multirow{3}{*}{1} & X5563 tumor & 4.0 & 117 \\
\hline & $\begin{array}{l}\text { X5563 tumor, } \\
\text { RNase treated }\end{array}$ & 4.0 & 59 \\
\hline & Ehrlich tumor & 3.3 & 55 \\
\hline \multirow{3}{*}{2} & X5563 tumor & 14.0 & 98 \\
\hline & $\begin{array}{l}\text { X5563 tumor } \\
\text { RNase treated }\end{array}$ & 14.0 & 53 \\
\hline & Ehrlich tumor & 14.0 & 52 \\
\hline
\end{tabular}

Ehrlich ascites cells were treated with each kind of RNA shown above for 15 hours at $2^{\circ} \mathrm{C}$ by gentle stirring, $30 \mathrm{rpm}$. Then ${ }^{14} \mathrm{C}$-leucine incorporation was done at $37^{\circ} \mathrm{C}$ for 2 hours.

myeloma protein to total soluble protein in ${ }^{14} \mathrm{C}$-leucine incorporation but incorporated ${ }^{14} \mathrm{C}$-leucine in myeloma protein represented by $\mathrm{cpm}$ was compared, because as the same concentration of RNA was used in each series of experiments, inhibition of protein synthesis by extracellular RNA could be cancelled. RNase treated RNA of X5563 tumor and Ehrlich tumor RNA have shown considerably lower activities to induce myeloma protein synthesis than X5563 RNA. Experimental conditions were almostly the same as mentioned in previous section. 


\section{DISCUSSION}

As already suggested by Potter (1960), gamma myeloma protein synthesis in X5563 tumor cells may possibly be a heritable character. In other words, DNA-dependent myeloma protein synthesis might require a specific messenger RNA. Actinomycin D, however, showed not complete inhibition in the myeloma protein synthesis. This result suggests the possibility that messenger RNA responsible for the myeloma protein synthesis might be quite stable. A similar finding has been recently obtained in the aggregability of chick embryo cell suspension (Moscona and Moscona 1963). In addition to this, the rate of myeloma protein synthesis to total protein synthesis in the cells is considerably high as reported by Askonas (1961). So, it is conceivable that large amount of RNA having a genic information specific to the myeloma protein synthesis is contained in the tumor cells.

Concerning protein synthesis in mammalian cells induced by the extracellular RNA, Niu et al. (1961, 1962) and Weisberger (1962) have demonstrated successful results. Flickinger (1963) suggested that a possible role of extracellular RNA in a series of works done by Niu et al. is non-specific activation of protein synthesis. But the result shown in Table 4 seems to indicate the specificity of X5563 tumor RNA in induction of myeloma protein synthesis. As laurylsulfate was used to extraction of RNA in the present experiment, RNA fraction obtained here might contain an appropriate amount of messenger RNA (cf. Hiatt 1962). The myeloma protein synthesis in Ehrlich ascites tumor cells demonstrated in Table 3 is probably induced by messenger RNA fraction of X5563 tumor.

It remains unknown the reason why Ehrlich tumor cells incorporated ${ }^{14} \mathrm{C}$-leucine into the myeloma protein fraction, even though they were not treated with $\mathrm{X} 5563$ RNA. Anti-myeloma rabbit serum used here must contain some non-specific substance which can react with the soluble proteins in Ehrlich tumor cells. Otherwise Ehrlich ascites tumor cells should be capable to produce myeloma-like protein in nature. Similar non-specific precipitation by anti-globulin rabbit serum as the observed here was also reported by Bonner (1963).

Another problem to be solved is how extracellular RNA inhibits protein synthesis. In this connection, Tissières (1963) demonstrated that free form of soluble RNA inhibits DNA dependent RNA polymerase in E. coli. This finding might partially explain the cause of inhibition of protein synthesis by RNA, because in the present experiment phenol was used to extract RNA fraction from tumor cells which is liable to split amino acid from amino acyl soluble RNA and to produce free form of soluble RNA.

\section{SUMMARY}

(1) Incorporation of ${ }^{14} \mathrm{C}$-leucine into myeloma protein fraction of X5563 plasma cell tumor in $\mathrm{C} 3 \mathrm{H}$ mouse was partially inhibited by actinomycin $\mathrm{D}$. This result sug- 
gests the existence of a stable messenger RNA in the tumor cells.

(2) The actinomycin-depressed myeloma protein synthesis could be restored following extracellular treatment with X5563 tumor RNA for 15 hours at $2^{\circ} \mathrm{C}$.

(3) Treatment with X5563 tumor RNA for 15 hours at $2^{\circ} \mathrm{C}$ could induce myeloma protein synthesis in Ehrlich ascites tumor cells. Neither RNase treated RNA of X5563 tumor nor RNA of Ehrlich tumor itself was capable of inducing the myeloma protein.

(4) In present experiments RNA treatments caused the inhibition of protein synthesis in the recipient cells in proportion of the concentration, although it had no inhibitory effect on the oxygen consumption of the cells. So, the ability of RNA restoring or inducing myeloma protein synthesis was expressed by a ratio of myeloma protein fraction to total soluble protein fraction in ${ }^{14} \mathrm{C}$-leucine incorporation. ${ }^{14} \mathrm{C}$-leucine incorporated into myeloma protein fraction was determined by the radioactivity in the precipitate with anti-myeloma rabbit serum.

\section{ACKNOWLEDGEMENTS}

The author wishes to express his cordal thanks to Drs. T. H. Yosida of this Institute and S. Kondo of Osaka University for their kind interests and encouragements during this work. The author is also grateful to Dr. M. Potter of the National Institutes of Health for his supply of the plasma cell tumor $(\times 5563)$ and Dr. M. Foster of the University of Michigan for his kindness in reading of the manuscript. Finally the manitenance of the plasma cell tumor strain by Mr. Y. Kurita is gratefully acknowledged.

This work was supported by grant from The Toyo Rayon Foundation for the Promotion of Science and Technology and partly supported by Grant-in-Aid of Ministry of Education of Japan, No. 95625 in 1963.

\section{LITERATURE CITED}

Askonas, B., 1961 A study on globulin formation by plasma-cell neoplasm (5563) transplantable in mice. Biochem. J. 79: 33-42.

Bonner, J., R. C. Huang and R. V. Gilden, 1963 Chromosomally directed protein synthesis. Proc. Nat. Acad. Sci. U.S. 50: 893-900.

Hiatt, H. H., 1962 A rapidly labeled RNA in rat liver nuclei. J. Mol. Biol. 5: 217-229.

Lamfrom, H., 1961 Factors determining the specificity of hemoglobin synthesized in a cell-free system. J. Mol. Biol. 3: 241-252.

Moscona, M. H. and A. A. Moscona, 1963 Inhibition of adhesiveness and aggregation of dissociated cells by inhibitors of protein and RNA synthesis. Science 142: 1070-1071.

Niu, M.C., C. C. Cordova and L.C. Niu, 1961 Ribonucleic acid-induced change in mammalian cells. Proc. Nat. Acad. Sci. U.S. 47: 1689-1700.

Niu, M. C., C. C. Cordova, L. C. Niu and C. L. Radbill, 1962 RNA-induced biosynthesis of specific enzymes. Proc. Nat. Acad. Sci. U.S. 48: 1964-1969.

Potter, M. and J. L. Fahey, 1960 Studies on eight transplantable plasma-cell neoplasms of mice. J. Nat. Cancer Inst. 24: 1153-1163.

Schweet, R., H. Lamfrom and E. Allen, 1958 The synthesis of hemoglobin in a cell-free system. Proc. Nat. Acad. Sci. U.S. 44: 1029-1035. 
Sibatani, A., S. R. De Kloet, V.G. Allfrey and A. E. Mirsky, 1962 Isolation of a nuclear RNA fraction resembling DNA in its base composition. Proc. Nat. Acad. Sci. U.S. 48: 471-477.

Szybalska, E. H. and W. Szybalski, 1962 Genetics of human cell lines. IV. DNA-mediated heritable transformation of biochemical trait. Proc. Nat. Acad. Sci. U.S. 48: 2026-2034.

Tissières, A., S. Bourgeois and F. Gros, 1963 Inhibition of RNA polymerase by RNA. J. Mol. Biol. 7: 100-103.

Weisberger, A. S., 1962 Induction of altered globulin synthesis in human immature erythrocytes incubated with ribonucleoprotein. Proc. Nat. Acad. Sci. U.S. 48: 68-80.

Weiss, S. B., 1960 Enzymatic incorporation of ribonucleoside triphosphates into the interpolynucleotide linkages of ribonucleic acid. Proc. Nat. Acad. Sci. U.S. 46: 1020-1030. 